\title{
Different Approaches to Managing Innovation Activities: An Analysis of Strong, Moderate, and Modest Innovators
}

\author{
Viktor Prokop, Jan Stejskal \\ University of Pardubice, Faculty of Economics and Administration \\ Studentska 95, CZ532 10 Pardubice, Czech Republic \\ E-mail.viktor.prokop@upce.cz; jan.stejskal@upce.cz \\ cross $^{\text {ref }}$ http://dx.doi.org/10.5755/j01.ee.28.1.16111
}

In the present day, innovation has become a key element of competitive advantage. However, most countries are failing in their innovative activities, and their innovative performance is below that of the EU average. Therefore, the European Commission annually publishes its Innovation Union Scoreboard, which provides a comparative assessment of the EU member states' research and innovation performance. The countries are divided into four groups according to their innovation performance: innovation leaders, strong innovators, moderate innovators, and modest innovators. In this paper, we have selected countries whose innovation performance was close to, below, or well below that of the EU average in 2015, and we have performed microeconomic analysis of the situation in these countries' firms to analyse the conditions of their innovation environment and uncover barriers to their innovation activities. We analysed firms in the manufacturing industries in Slovenia (a strong innovator), Croatia (a moderate innovator), and Romania (a modest innovator) by using original multiple regression models and data from the 2010-2012 Community Innovation Survey. The results demonstrate the different backgrounds for innovation in each country. In Romania, there is a lack of both a satisfactory environment for innovation and sufficient capacity for absorbing public funds; investment into innovation-related activities is also absent. In Croatia, the innovation potential has not been fully exploited. However, we show that the appropriate targeting of innovation determinants (e.g., collaboration with different partners or public financing) could lead to the creation of synergies and spillover effects that would be able to support their innovative activities and strengthen the country's competitiveness. There is a completely different situation in Slovenia. Firms there effectively utilize the various determinants of innovation activities, and these determinants have strong influence when utilized on their own. On the other hand, results also show that certain significant combinations of determinants of innovation activities are missing in Slovenia. In conclusion, we have proposed practical implications for policy makers that would be able to support innovative activities and help each country to improve its innovation ranking.

Keywords: Innovation, Entrepreneurs, Innovation Management, Strong, Moderate, Modest Innovators.

\section{Introduction}

Today, in the era of the knowledge economy, most industries are characterized by rapidly changing environments (Miguel \& Jorge, 2003) where knowledge, research, and innovation are key to building competitive advantage, value added, and a prosperous future. However, proficiency in managing innovation is a necessary condition for the survival of a country or organization, although it is not sufficient on its own. This is clear, because not every innovative company achieves better results, and not every country that uses knowledge is knowledge-based. Indeed, innovation can take many forms (product, service and process, or marketing), and the creation of innovation is a complex process that is affected by a number of determinants. Huber (1998) claimed that the relationship between different factors (internal/external), organizational creativity and learning, and innovation are bidirectional, synergistic, and able to lead to the creation of spillover effects. Thus, knowledge represents a traditional public good that still seems to be the most well-known and accepted justification for policy intervention (Cerulli, 2010), and it is in the interest of public policy makers to support these interactions by using different types of innovation policy instruments. Borras and
Edquist (2013) examined how governments and public agencies have used these instruments differently in different countries at different times and state that innovation policy instruments must be designed carefully on the basis of an innovation system perspective and must be combined in ways that address the complex problems of each country's innovation processes - specifically, in each of the national economy's industries.

Therefore, knowledge, research, and innovation figure prominently in the Europe 2020 strategy and the European Commission annually publishes its Innovation Union Scoreboard, which provides a comparative assessment of the EU member states' research and innovation performance. The countries are divided into groups according to their innovation performance: innovation leaders (e.g., Germany and Sweden); strong innovators (e.g., Slovenia and France); moderate innovators (e.g., Croatia and Hungary); and modest innovators (e.g., Bulgaria and Romania). All the countries and the innovation performance groups to which they belong are shown in Figure 1. 


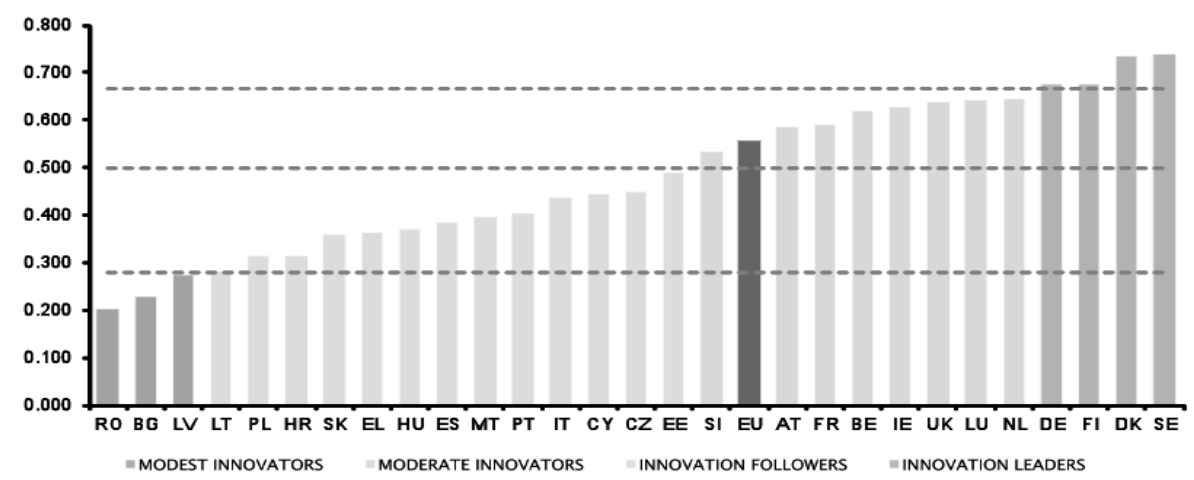

Figure 1. Innovation Performance in 2015

Source: Innovation Union Scoreboard 2015

In fact, the European Commission essentially provides macroeconomic analysis of each member state's innovation performance to help assess the areas in which they need to concentrate their efforts in order to boost their innovation performance. However, we claim that it is also necessary to perform microeconomic analysis to examine the innovation conditions and barriers at the firm level in each country. Therefore, the aim of this paper is (a) to choose countries whose innovation performance was close to, below, or well below that of the EU average in 2015; (b) to analyse the entrepreneurial innovation environment within industries; and (c) to examine the innovation conditions and barriers at the microeconomic level. Specifically, analyses were conducted for the Slovenian (strong innovator), Croatian (moderate innovator), and Romanian (modest innovator) manufacturing industries. The remainder of the article is organized as follows: the first section describes the theoretical background; data and methodology are described in the second part; and, next, the results are discussed. Conclusions and practical implications are listed in the last section.

\section{Theoretical Background}

Earlier approaches to innovation activities are based on the fact that the firm is the best place for innovation and the implementation of innovation processes (Gambardella, 1992; Siddharthan, 1992; Kumar \& Saqib, 1996; Veugelers \& Cassiman, 1999). In these, processes took place without external interactions, and information from competitors and other external players was very rarely incorporated. The substance of this "lock-in strategy" was to keep the emerging innovation secret and not to allow competitors to respond before the firm was able to put the innovations on the market. The advantages of this approach are gaining a competitive advantage in the market, the broad commercialization of innovation, and obtaining additional funds for expanding innovation and financing subsequent in-house R\&D activities (Narula, 2002; Chesbrough, 2010). The disadvantages include the time required for creating innovation and the inability to share the costs of research and development moreover, it was not possible to share knowledge. This type of firm must make a large investment into R\&D facilities and technologies; such firms have very high costs for organizing and managing in-house innovation. Frequently, even these high costs did not create enough pressure on the firms to cause them to approach the market and obtain the necessary knowledge and technology there. However, there are some studies from the middle of the 20th century (for example, Nelson, 1959) that point to the occasional inefficiency of this model. According to them, this model did not always prevent spillovers, which reduced the effectiveness of the innovation process as a whole.

Current models of innovation activities in firms are based on an open innovation paradigm; the R\&D structure should be seen as an open system (Chesbrough, 2003; Chesbrough, 2006). These approaches assume that faster and cheaper innovation processes can be achieved by using external knowledge and stimuli, financial resources, experience, and spillover effects. This does not mean a deflection from using internal ideas and sources. A firm must always be founded on its own knowledge and the available technologies that form the basis of its innovation portfolio. It has been demonstrated that a firm is not the most suitable environment for the creation of innovation. An open R\&D system allows firms to outsource R\&D projects or technologies with no clear paths to market. By being exposed to external partners, these R\&D projects may eventually find their way to market. It also allows firms to insource external ideas through the integration of suppliers, customers, and external knowledge sources to increase firm innovativeness (Berchicci, 2013). Some scholars point out the negative aspect/s of the open innovation approach. Some companies may (after their first positive experience) also start to rely on external sources of knowledge and innovation stimuli in the future. Firms that depend entirely on external partners may lack internal R\&D processes and the ability to fully obtain and assimilate external knowledge. They agree, however, that firms also realize that some R\&D activities in non-core technology areas are not firm-specific and, therefore, it is possible either to have joint R\&D activities with other partners or to outsource some of them because of the benefits of cost saving and innovative output (Hagedoorn, 2002).

There are some studies that emphasize that the open innovation approach gives companies benefits greater than just cost savings (Dyer \& Singh, 1998; Grant, 1996; Parida, Westerberg, \& Frishammar, 2012; Reed, Storrud-Barnes, \& Jessup, 2012; Wang, Vanhaverbeke, \& Roijakkers, 2012; Cheng \& Huizingh, 2014; etc.). They highlight that knowledge sharing and inter-firm linkages allow the firms to achieve greater efficiency and performance. The reasons for this are the speed of new technologies and knowledge development and the rapidly changing innovation, technology, and knowledge environments (Stejskal \& Hajek, 
2015). Innovation processes have been affected by a new element: outsourcing in science and research. This is a way for companies to provide all the necessary technological elements, increase their limited innovative ability, and focus all activities solely on technology and knowledge management. We are able to distinguish several types of this depending on what is outsourced, i.e., technological or knowledge outsourcing.

There are several possibilities for firms to obtain knowledge for their innovative activity. One way is to invest in internal technology and research. It appears, however, that focusing only on internal $R \& D$ and the development of internal capabilities and routines is no longer sufficient to cope with increasing costs, shorter product life cycles, and greater technological complexities. Some studies (for example, Hagedoorn, 2002; Mowery, 2009; Berchicci, 2013) have demonstrated that, as of the 1990s, drivers had already drastically mutated organizations, where the monolithic structure of internally closed $\mathrm{R} \& \mathrm{D}$ has been rapidly fading and shifting from a vertically integrated in-house $R \& D$ structure to an open R\&D structure by tapping into external sources of knowledge through licensing, alliances, and technology agreements.

There are studies that deal with sources of knowledge acquisition. Some of these deal with the influence of knowledge acquisition for the internationalization of smaller firms (Ginevicius \& Korsakiene, 2005; Fletcher \& Harris, 2012); some answer the question of how localized social capital affects innovation and external knowledge acquisition (Laursen, Masciarelli, \& Prencipe, 2012); and others focus on knowledge acquisition and the moderate effects of internal knowledge transfer or knowledge acquisition gaps (Yang \& Grabe, 2011). The studies agree that knowledge has a positive influence on corporate performance (Prochazka \& Hajek, 2015; Tseng, 2014). Only some of these studies deal with the impact of knowledge acquisition sources on performance (e.g., Cruz-Gonzalez et al., 2014, analyse the impact on performance in high-technology industries; Rasul, Vuksic, \& Stemberger, 2012, deal with the impact on organizational innovations; and Garcia Martinez et al., 2014, focus on the impact of the open innovation strategy on performance).

Some studies indicate that inter-firm linkages and technology outsourcing allow firms to keep up with new developments so that they can increase the learning gains from cooperation. The extension of a firm's technological capabilities increases the chances of developing and realizing new products (Becker \& Dietz, 2004). Higher performance can be brought about by trust, long-term relationships based on mutual trust and cooperation, incorporation into dynamic networks and industrial clusters, an appropriately designed regional innovation system, and other elements of regional policies that help create a knowledge-based learning environment. Whenever innovative firms use these advanced features, it has a positive impact on their innovation capabilities, total productivity, and thus ensures a return on investment.

Following the arguments above, the aim of this article is to analyse situation in companies and examine the conditions and barriers to innovation at the firm level in countries whose innovation performance was close to, below, or well below that of the EU average in 2015 - concretely, in the Slovenian (strong innovator), Croatian (moderate innovator), and
Romanian (modest innovator) manufacturing industries between 2010-2012. We assume that each country has completely different conditions for and barriers to firm innovation activities, because they represent different innovation performance groups.

\section{Data and Methodology}

Data for the analyses were obtained from the Community Innovation Survey for 2010-2012. The Community Innovation Survey (CIS) is a harmonized questionnaire, which is part of the EU's science and technology statistics; it is carried out every two years by the EU member states and a number of ESS member countries. For our analysis, we created original multiple linear regression models to investigate the relationship between one dependent variable, represented by the $\%$ of turnover in new or improved products introduced during 2010-2012 (new to the market), and a number of selected independent variables, innovation activity determinants. (The relationships examined between dependent and independent variables are shown in Figure 2, and all independent variables are shown in Table 1 at the end of this section.) In total, we analysed 3,982 Romanian, 1,280 Croatian, and 918 Slovenian firms in the manufacturing industries (NACE Categories 10-33).

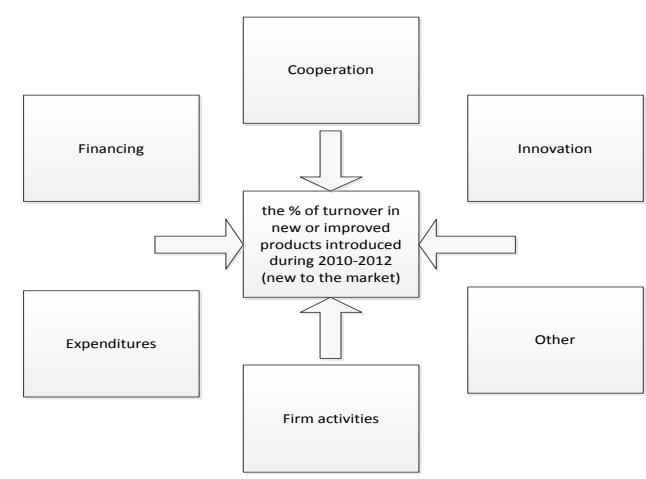

Figure 2. Variables in the Analyses

Regression models are commonly used for this kind of analysis (e.g., Nieto \& Quevedo, 2005; Chen \& Huang, 2009; Schneider \& Spieth, 2013) and take the general form as follows (Chatterjee \& Hadi, 2013):

$$
y=\beta_{0}+\beta_{1} x_{1}+\beta_{2} x_{2}+\ldots+\beta_{n} x_{n}+\varepsilon
$$

where

$y$ is a dependent variable;

$x_{1}, x_{2} \ldots x_{n}$ are independent variables;

$\varepsilon$ is an error term that accounts for the variability in $y$ that cannot be explained by the linear effect of the $n$ independent variables;

$\beta_{1}, \beta_{2} \ldots \beta_{n}$, called the regression parameters or coefficients, are unknown constants to be determined (estimated) from the data.

Verification of whether the data from the CIS were correlated was conducted using Spearman's test. Spearman's coefficient $\left(r_{s}\right)$ measures the strength of the linear relationship between each two variables when the values of each variable are rank-ordered from 1 to $N$, where $\mathrm{N}$ represents the number of pairs of values (the $N$ cases of each variable are assigned integer values from 1 to $N$ inclusive, and no two cases share the same value). The difference between ranks for each case 
Viktor Prokop, Jan Stejskal. Different Approaches to Managing Innovation Activities: An Analysis of Strong, Moderate...

is represented by $d_{i}$. The general formula for Spearman's rank correlation coefficient takes the general form as follows (Weinberg \& Abramowitz, 2002; Borradaile, 2013):

$$
r_{s}=1-\frac{6 \sum d_{i}^{2}}{N^{3}-N}
$$

All calculations were made using the statistical software STATISTICA (StatSoft Inc., 2011). The values of Spearman's test rejected the hypothesis that the data are correlated with a level of significance at $p<0.05$. After fulfilling the first prerequisite (uncorrelated data) and the rejection of multicollinearity in the model, the analysis itself was conducted.

Table 1

Independent Variables

\begin{tabular}{|c|c|c|c|c|c|}
\hline Financing & Cooperation & Innovation & Expenditures & Firm Activities & Other \\
\hline $\begin{array}{l}\text { Public funding from } \\
\text { local or regional } \\
\text { authorities } \\
\text { (FUNLOC) }\end{array}$ & $\begin{array}{l}\text { Cooperation } \\
\text { arrangements on } \\
\text { innovation activities } \\
\text { (CO) }\end{array}$ & $\begin{array}{l}\text { Introduced a new or } \\
\text { significantly improved } \\
\text { product into the market } \\
\text { (INN_G) }\end{array}$ & $\begin{array}{l}\text { Intramural R\&D } \\
\text { (RRDIN) }\end{array}$ & $\begin{array}{l}\text { Merge with or take over } \\
\text { another enterprise } \\
\text { (ENMRG) }\end{array}$ & $\begin{array}{l}\text { The largest market in } \\
\text { terms of turnover } \\
\text { between 2010-2012 } \\
\text { (LARMAR) }\end{array}$ \\
\hline $\begin{array}{l}\text { Public funding from } \\
\text { the central } \\
\text { government } \\
\text { (FUNGMT) }\end{array}$ & $\begin{array}{l}\text { Other enterprises } \\
\text { within an enterprise } \\
\text { group (COGP) }\end{array}$ & $\begin{array}{l}\text { Introduced a new or } \\
\text { significantly improved } \\
\text { service into the market } \\
\text { (INN_S) }\end{array}$ & $\begin{array}{l}\text { Extramural R\&D } \\
\text { (RRDEX) }\end{array}$ & $\begin{array}{l}\text { Sell, close, or outsource } \\
\text { some of the company's } \\
\text { tasks or functions } \\
\text { (ENOUT) }\end{array}$ & $\begin{array}{l}\text { Participation in a } \\
\text { group of enterprises } \\
\text { (GP) }\end{array}$ \\
\hline \multirow[t]{6}{*}{$\begin{array}{l}\text { Public financial } \\
\text { support from the EU } \\
\text { (FUNEU) }\end{array}$} & $\begin{array}{l}\text { Suppliers of } \\
\text { equipment, materials, } \\
\text { components, or } \\
\text { software (COSUP) }\end{array}$ & $\begin{array}{l}\text { Introduced a new or } \\
\text { significantly improved } \\
\text { process into the market: } \\
\text { method of production; } \\
\text { logistic, delivery, or } \\
\text { distribution system; } \\
\text { supporting activities } \\
\text { (INN_P) }\end{array}$ & $\begin{array}{l}\text { Acquisition of } \\
\text { machinery (RMAC) }\end{array}$ & $\begin{array}{l}\text { Establish new subsidiaries } \\
\text { in [home country] or in } \\
\text { other European countries } \\
\text { (ENNWEUR) }\end{array}$ & \\
\hline & $\begin{array}{l}\text { Clients or customers } \\
\text { (COCUS) }\end{array}$ & & $\begin{array}{l}\text { Acquisition of external } \\
\text { knowledge (ROEK) }\end{array}$ & $\begin{array}{l}\text { Establish new subsidiaries } \\
\text { outside Europe } \\
\text { (ENNWOTH) }\end{array}$ & \\
\hline & $\begin{array}{l}\text { Consultants and } \\
\text { commercial labs } \\
(\text { COCONS })\end{array}$ & & $\begin{array}{l}\text { All other activities } \\
\text { (ROTR) }\end{array}$ & & \\
\hline & $\begin{array}{l}\text { Competitors or other } \\
\text { enterprises in the sector } \\
(\mathrm{COCOMP})\end{array}$ & & $\begin{array}{l}\text { Total expenditures on } \\
\text { innovation activities } \\
\text { (RALL) }\end{array}$ & & \\
\hline & $\begin{array}{l}\text { Universities or other } \\
\text { higher education } \\
\text { institutions (COUNI) }\end{array}$ & & & & \\
\hline & $\begin{array}{l}\text { Government or public } \\
\text { research institutes } \\
(\mathrm{COGOV})\end{array}$ & & & & \\
\hline
\end{tabular}

Legend: The $\%$ of total turnover in 2012 was used to determine expenditures.

\section{Results and Their Analysis}

First, we analysed the relationship between each of the independent variables (the determinants of innovative activities) and the target variable (the growth of turnover from innovated products between 2010-2012) by using original multiple regression models. Table 2 shows the results of the individual models for the manufacturing industries of each country. The results in Table 2 show that each country has a different innovation environment.

Table 2

The Effects of the Determinants of Innovation Activities in Romania, Croatia, and Slovenia

\begin{tabular}{|l|l|l|l|}
\hline \multirow{5}{*}{ Variables } & $\begin{array}{l}\text { Modest } \\
\text { Innovator }\end{array}$ & $\begin{array}{l}\text { Moderate } \\
\text { Innovator }\end{array}$ & Strong Innovator \\
\cline { 2 - 4 } & Romania & Croatia & \\
& $R=0.983 ;$ & $R=0.616 ;$ & Slovenia \\
& $R^{2}=0.967$ & $R^{2}=0.380$ & $R=0.997 ; R^{2}=0.995$ \\
& $p=0.045$ & $p=3.35 \mathrm{E}-11$ & $p=1.40 \mathrm{E}-5$ \\
\hline FUNLOC & - & 0.718 & - \\
\hline FUNGMT & - & 0.117 & 0.434 \\
\hline FUNEU & $0.059^{*}$ & - & $0.000^{* * *}$ \\
\hline CO & 0.739 & - & - \\
\hline COGP & $0.065^{*}$ & - & - \\
\hline COSUP & - & - & - \\
\hline COCUS & - & $0.035^{* *}$ & $0.000^{* * *}$ \\
\hline
\end{tabular}

\begin{tabular}{|l|l|l|l|}
\hline \multirow{5}{*}{ Variables } & $\begin{array}{l}\text { Modest } \\
\text { Innovator }\end{array}$ & $\begin{array}{l}\text { Moderate } \\
\text { Innovator }\end{array}$ & Strong Innovator \\
\cline { 2 - 4 } & Romania & Croatia & Slovenia \\
& $R=0.983 ;$ & $R=0.616 ;$ & $R=0.997 ; R^{2}=0.995$ \\
& $R^{2}=0.967$ & $R^{2}=0.380$ & $p=1.40 \mathrm{E}-5$ \\
& $p=0.045$ & $p=3.35 \mathrm{E}-11$ & - \\
\hline COCONS & - & - & - \\
\hline COCOMP & - & $0.055^{*}$ & - \\
\hline COUNI & $0.055^{*}$ & 0.149 & $0.000^{* * *}$ \\
\hline COGOV & $0.070^{*}$ & 0.128 & - \\
\hline INN_G & - & - & $0.009 * * *$ \\
\hline INN_S & $0.076^{*}$ & - & 0.729 \\
\hline INN_P & 0.104 & - & - \\
\hline RRDIN & - & 0.825 & $0.000^{* * *}$ \\
\hline RRDEX & $0.034^{*}$ & 0.569 & 0.173 \\
\hline RMAC & - & 0.701 & 0.269 \\
\hline ROEK & - & 0.653 & 0.702 \\
\hline ROTR & - & 0.569 & 0.927 \\
\hline RALL & $0.054^{*}$ & - & - \\
\hline ENMRG & - & 0.482 & 0.743 \\
\hline ENOUT & $0.082^{*}$ & $0.000^{* * *}$ & $0.008^{* * *}$ \\
\hline ENNWEUR & - & - & - \\
\hline ENNWOTH & - & - & $0.002^{* * *}$ \\
\hline LARMAR & - & 0.186 & - \\
\hline GP & - & - & \\
\hline
\end{tabular}

Legend: The table shows the results of the $p$-values in each model.

$*$ significant at $p<0.1 ; * *$ significant at $p<0.05 ; * * *$ significant at $p<0.01$

Source: Authors' own research. 
In Romania, a background in innovation is missing and therefore determinants of innovative activities are not able to influence the growth of turnover from innovation. This is one of the signs of an innovation paradox, which these countries (especially modest innovators) may suffer. An innovation paradox refers to the apparent contradiction between the comparatively greater need to spend on innovation in lagging regions and their relatively lower capacity to both absorb public funds earmarked for the promotion of innovation and invest in innovation related activities (as we can see in Table 2 - FUNLOC, FUNGMT, FUNEU) as compared to more advanced regions or countries (Oughton et al., 2002). In Croatia, the situation is similar. Most of the determinants do not influence the growth of turnover from innovation on their own. ENOUT (sell, close, or outsource some of the company's tasks or functions) and COCUS (cooperation with clients or customers) were most significant. On the other hand, in Slovenia (a strong innovator), firms in the manufacturing industry effectively utilize the various determinants of innovation activities, and these determinants have strong influence on the growth of turnover from innovation (e.g., financing from the EU, cooperation with clients or customers, cooperation with public research institutes, and expenditures in extramural R\&D).

As we claimed above, the relationship between different factors (internal/external), organizational creativity and learning, and innovation are bidirectional, synergistic, and lead to the creation of spillover effects. Other authors have also confirmed that innovation does not arise in isolation rather, it does, but companies could achieve better results without isolation (e.g., Herstad et al., 2014; Hall \& Wylie, 2014). Consequently, we analysed combinations of determinants of innovation activities that could lead to the creation of synergies and spillover effects.

\section{Analysis of the Influence of Innovation Activity Determinants in Combination}

Most studies analyse the spatial distribution of innovative activities and the role of technological spillovers in the process of knowledge creation and diffusion across firms, regions, and countries (e.g., Moreno et al., 2005; CabrerBorras \& Serrano-Domingo, 2007; Lee et al., 2015). The emergence of spillover effects occur mainly in countries belonging to the innovation leaders group. For example, Fritsch and Franke (2004) investigated the impact of knowledge spillovers and R\&D cooperation on innovation activities in German regions; Andersson and Ejermo (2005) showed that there is a positive relationship between the innovativeness of a corporation and its accessibility to university researchers in Sweden; and Dahl (2002) and Engelstoft et al. (2006) analysed knowledge flows within clusters in Denmark with respect to spillover effects as a positive technological externality. Therefore, we analysed whether positive spillover effects also occur within countries from other innovation performance groups (strong innovators - Slovenia; moderate innovators - Croatia; modest innovators - Romania).

In Romania, spillover effects rarely occurred because of a lack of innovative background and facilities. The results in Table 2 show the importance of cooperation with universities and public research institutes in the manufacturing industry in Romania. For example, if a company simultaneously introduced process innovations and cooperated with universities, this causes effects influencing the growth of turnover from innovations $\left(0.046^{* *}\right)$. Also, the provision of EU funds led to the creation of significant effects in some cases - in cooperation with universities $\left(0.045^{* *}\right)$ and in cooperation with public research institutes $(0.042 * *)$

Table 3

The Influence of Cooperation on Innovative Activities in Romania

\begin{tabular}{|l|l|l|}
\hline Variables & $\begin{array}{l}\text { Universities (or Other } \\
\text { Higher Education } \\
\text { Institutions) }\end{array}$ & $\begin{array}{l}\text { Public Research } \\
\text { Institutes (or the } \\
\text { Government) }\end{array}$ \\
\hline FUNEU & $0.045^{* *}$ & $0.042^{* *}$ \\
\hline INN_S & - & $0.048^{* *}$ \\
\hline INN_P & $0.046^{* *}$ & $0.065^{*}$ \\
\hline COGP & $0.055^{*}$ & $0.052^{*}$ \\
\hline Legend: significant at $p<0.1 ; * *$ significant at $p<0.05 ; * * *$ significant at \\
$p<0.01$ \\
\multicolumn{2}{|c|}{ Source: Authors'own research. }
\end{tabular}

The results in Table 3 show that firms in Croatia's manufacturing industry were able to significantly influence their growth of turnover from innovation by using the appropriate cooperation partners. In Croatia, as is shown in Table 1, the determinants of innovation activities do not influence firms' growth of turnover from innovation in isolation. Companies are not able to benefit from these determinants, and they consequently fail to increase innovation output. On the other hand, companies that choose proper cooperation partners (universities and public research institutes) and other determinants of innovation activities (e.g., FUNLOC, FUNGMT, LARMAR, and ENOUT) significantly influenced their turnover from innovations.

Table 4

The Influence of Cooperation on Innovative Activities in Croatia

\begin{tabular}{|l|c|c|c|}
\hline \multicolumn{1}{|c|}{ Variables } & $\begin{array}{c}\text { Universities (or Other Higher } \\
\text { Education Institutions) }\end{array}$ & $\begin{array}{c}\text { Public Research Institutes (or } \\
\text { the Government) }\end{array}$ & $\begin{array}{c}\text { Competitors (or Other } \\
\text { Enterprises in the Sector) }\end{array}$ \\
\hline FUNLOC & $0.001^{* * *}$ & 0.380 & $0.006^{* * *}$ \\
\hline FUNGMT & $0.000^{* * *}$ & $0.004 * * *$ & 0.465 \\
\hline ENOUT & $0.016^{* *}$ & $0.020^{* *}$ & 0.714 \\
\hline ENMRG & $0.024 * *$ & $0.022^{* *}$ & 0.331 \\
\hline COGOV & $0.029 * *$ & - & $0.018^{* *}$ \\
\hline COUNI & - & $0.029^{* *}$ & $0.001 * * *$ \\
\hline COCUS & $0.001 * * *$ & $0.018^{* *}$ & - \\
\hline COCOMP & 0.765 & 0.645 & 0.756 \\
\hline LARMAR & $0.011^{* *}$ & $0.008^{* * *}$ & 0.941 \\
\hline
\end{tabular}

Legend: significant at $p<0.1 ; * *$ significant at $p<0.05$; *** significant at $p<0.01$

Source: Authors' own research. 
Viktor Prokop, Jan Stejskal. Different Approaches to Managing Innovation Activities: An Analysis of Strong, Moderate...

In Slovenia, interactions of determinants occurred rarely, even though firms effectively utilize the various determinants of innovation activities, and these determinants have strong influence on the growth of the firms' turnover from innovation in the manufacturing industry on their own.

Table 5

The Influence of Cooperation on Innovative Activities in Slovenia

\begin{tabular}{|c|c|c|c|c|c|c|c|c|}
\hline & FUNEU & FUNGMT & COGOV & COCUS & ENOUT & ENWEUR & LARMAR & INN_P \\
\hline $\begin{array}{l}\text { Introduced a new or significantly } \\
\text { improved service into the market }\end{array}$ & $0.012 * *$ & - & $0.000 * * *$ & - & $0.023 * *$ & - & $0.002 * * *$ & - \\
\hline
\end{tabular}

Legend: * significant at $p<0.1$; ** significant at $p<0.05$; *** significant at $p<0.01$

Source: Authors' own research.

Table 4 shows that only service innovation had strong influence in combination with other determinants (e.g., FUNEU: $0.012 * *$ and COGOV: $0.000 * * *)$. These results point to the fact that, in Slovenia, there is an appropriate background for innovation and suitable absorption capacity, thanks to which companies are able to utilize innovative determinants in isolation. Consequently, these companies are not forced to seek new sources of competitive advantage and change their current situation, because they are relatively successful in innovation. Narula (2002) states that firms are by definition resistant to radical change, and firms will always to prefer to maintain the status quo if it does not endanger their competitiveness (firms are often slow in changing their dominant designs, because they are path dependent and technologically locked in). By their very nature, all innovation systems have some degree of inertia, and this may lead to lock-in. Moreover, while offering a veneer of protection to existing systems in the shorter term, innovation lock-in tends to create barriers to more sustainable innovation (Aylward, 2006); this can lead to a country's decline in innovation performance as well as a decline in its competitive advantage and prosperity.

\section{Conclusion and Implications}

Innovation plays an important role in most national policies and figures prominently in the Europe 2020 strategy, because it unequivocally leads to an increase in the well-being and competitiveness of individual economic entities. For this reason, the European Commission annually measures innovation performance and publishes the Innovation Union Scoreboard, which provides a comparative assessment of the research and innovation performance of the EU Member States. For this purpose, the EU countries have been divided into four groups according to their innovation performance: innovation leaders (e.g., Germany and Sweden); strong innovators (e.g., Slovenia and France); moderate innovators (e.g., the Czech Republic and Hungary), and modest innovators (e.g., Bulgaria and Romania). In this article, we argue that this macroeconomic analysis must be expanded to incorporate microeconomic analysis within individual countries at the firm level. Therefore, we selected countries whose innovation performance was close to, below, or well below that of the EU average in 2015 and analysed the situation of companies in the manufacturing industries in Slovenia (a strong innovator), Croatia (a moderate innovator), and Romania (a modest innovator) using original multiple regression models and data from the 2010-2012 Community Innovation Survey. The results showed that the situation is different in each country and confirmed our claim stated above. Therefore, we would like to pose the following individual practical political implications.

Representing the modest innovators, Romania is a typical example of a country where there is an innovation paradox. In this country, a background for innovation is missing, and the country faces obstacles in elements of its environment (e.g., insufficient infrastructure). Therefore, determinants of innovative activities are not able to influence the growth of turnover from innovation even if they were provided with sufficient public funds. The country struggles with a lack of absorption capacity but may also be hampered by a lack of demand for innovation outputs (from both enterprises and research organizations). Therefore, we strongly suggest coordinating public policies, building sufficient infrastructure in the country, supporting the identification of innovative needs and the demand for innovation outputs, and helping promote trust among organizations.

In Croatia (representing the moderate innovators), the situation was initially similar to that in Romania and most of the determinants did not influence the growth of turnover from innovation on their own. On the other hand, the companies in Croatia's manufacturing industry that chose suitable cooperation partners (universities and public research institutes) and successfully targeted other determinants of innovation activities (e.g., public financing and market orientation) significantly influenced their turnover from innovations. This is a typical example of creating synergies and spillover effects. Therefore, we would suggest strengthening cooperation with universities and public research institutes in addition to focusing on promoting cooperation with clients and customers - and with competitors, because this kind of cooperation has not yet led to significant results. Collaboration with clients is an important element of competitive advantage, as evidenced, for example, by the lead user theory, which states that usercentered innovation is a very powerful and general phenomenon that supports innovative activities (Von Hippel 1986, 2005). Also, cooperation with competitors can lead to significant results. Gnyawali and Park (2011) state that coopetition (the simultaneous pursuit of collaboration and competition) is viewed as the sum of many different relationships, and the cooperative and competitive parts are divided between different actors. They also state that it occurs, evolves, and impacts the participating firms and the industry and that it plays an important role in enhancing common benefits as well as in gaining a proportionately larger share of the benefits. Co-opetition is a challenging yet very helpful way for firms to address major technological challenges, create benefits for partnering firms, and advance technological innovation. Moreover, co-opetition between 
giants causes subsequent collaboration among other firms and results in advanced technological development.

In Slovenia (a strong innovator), firms in the manufacturing industry effectively utilized the various determinants of innovation activities, and these determinants strongly influenced the growth of turnover from innovation (e.g., financing from the EU, cooperation with clients or customers, cooperation with public research institutes, and expenditures in extramural $\mathrm{R} \& \mathrm{D})$. On the other hand, interaction between these determinants rarely occurred; this points to the fact that Slovenia has an appropriate innovation background and absorption capacity, thanks to which companies are able to utilize innovative determinants in isolation. However, these companies are not forced to seek new sources of competitive advantage and change their current situation, because their innovation activities are relatively successful. Companies protect their know-how; there is no trust between firms or between firms and universities or public research institutes, which leads to a lack of cooperation and the lock-in effect. Narula (2002) states that this type of small country, for instance, simply does not have the resources to sustain world-class competences in as wide a variety of technologies as the economy may require. As such, the knowledge infrastructure may be unable to overcome lock-in as rapidly as firms need to sustain their competitiveness. However, as we stated above, innovation lock-in, while offering a veneer of protection to existing systems in the shorter term, tends to create barriers to more sustainable innovation, and this could lead to a decline in a country's innovation performance as well as to a decline in its competitive advantage and prosperity. We therefore propose greater company openness and promoting trust and cooperation between firms as well as between firms and universities or public research institutes. In Slovenia, an open innovation approach is necessary to develop and promote to use of purposive inflows and outflows of knowledge to accelerate internal innovation and expand the markets for external use of innovation. This concept is based on different research trends and suggests that valuable ideas can come from inside or outside the company and can also go to market from inside or outside the company (Chesbrough, 2006; Chesbrough \& Appleyard, 2007). Therefore, cooperation is seen as a crucial way to increase firms' growth of turnover and a country's competitiveness.

In future research, we plan to analyse and compare the situation for firms within each group of innovators (innovation leaders, strong innovators, moderate innovators, and modest innovators) and to propose practical implications that would be able to help firms as well as EU member states improve their competitiveness and innovation performance.

\section{Acknowledgments}

This paper was created as part of research task No. 17-11795S, "Modelling the Dynamics and Determinants of National and Regional Productivity Based on Knowledge and Cooperative Effects."

\section{References}

Andersson, M., \& Ejermo, O. (2005). How does accessibility to knowledge sources affect the innovativeness of corporations?- evidence from Sweden. The annals of regional science, 39(4), 741-765. https://doi.org/10.1007/s00168005-0025-7

Aylward, D. (2006). Innovation lock-in: unlocking research and development path dependency in the Australian wine industry. Strategic Change, 15(7/8), 361-372. https://doi.org/10.1002/jsc.768

Becker, W., \& Dietz, J. (2004). R\&D cooperation and innovation activities of firms - evidence for the German manufacturing industry. Research policy, 33(2), 209-223. https://doi.org/10.1016/j.respol.2003.07.003

Berchicci, L. (2013). Towards an open R\&D system: internal R\&D investment, external knowledge acquisition and innovative performance. Research Policy, 42(1), 117-127. https://doi.org/10.1016/j.respol.2012.04.017

Borradaile, G. J. (2013). Statistics of earth science data: their distribution in time, space and orientation. Springer Science $\&$ Business Media.

Borras, S., \& Edquist, C. (2013). The choice of innovation policy instruments. Technological forecasting and social change, 80(8), 1513-1522. https://doi.org/10.1016/j.techfore.2013.03.002

Cabrer-Borras, B., \& Serrano-Domingo, G. (2007). Innovation and R\&D spillover effects in Spanish regions: A spatial approach. Research Policy, 36(9), 1357-1371. https://doi.org/10.1016/j.respol.2007.04.012

Cerulli, G. (2010). Modelling and measuring the effect of public subsidies on business R\&D: a critical review of the econometric literature. Economic Record, 86(274), 421-449. https://doi.org/10.1111/j.1475-4932.2009.00615.x

Cruz-Gonzalez, J., Lopez-Saez, P., Emilio Navas-Lopez, J., \& Delgado-Verde, M. (2014). Directions of external knowledge search: investigating their different impact on firm performance in high-technology industries. Journal of Knowledge Management, 18(5), 847-866. https://doi.org/10.1108/JKM-06-2014-0243

Dahl, M. (2002). Embedded knowledge flows through labor mobility in regional clusters in Denmark. In DRIUD Summer Conference on "Industrial Dynamics of the New and Old Economy-who is embracing whom.

Dyer, J. H., \& Singh, H. (1998). The relational view: cooperative strategy and sources of interorganizational competitive advantage. Academy of Management Review, 23(4), 660-679.

Engelstoft, S., Jensen-Butler, C., Smith, I., \& Winther, L. (2006). Industrial clusters in Denmark: Theory and empirical evidence. Papers in Regional Science, 85(1), 73-98. https://doi.org/10.1111/j.1435-5957.2006.00067.x 
Viktor Prokop, Jan Stejskal. Different Approaches to Managing Innovation Activities: An Analysis of Strong, Moderate...

Fletcher, M., \& Harris, S. (2012). Knowledge acquisition for the internationalization of the smaller firm: Content and sources. International Business Review, 21(4), 631-647. https://doi.org/10.1016/j.ibusrev.2011.07.008

Fritsch, M., \& Franke, G. (2004). Innovation, regional knowledge spillovers and R\&D cooperation. Research policy, 33(2), 245-255. https://doi.org/10.1016/S0048-7333(03)00123-9

Gambardella, A. (1992). Competitive advantages from in-house scientific research: the US pharmaceutical industry in the 1980s. Research Policy, 21(5), 391-407. https://doi.org/10.1016/0048-7333(92)90001-K

Garcia Martinez, M., Lazzarotti, V., Manzini, R., \& Sanchez Garcia, M. (2014). Open innovation strategies in the food and drink industry: determinants and impact on innovation performance. International Journal of Technology Management, 66(2), 212-242. https://doi.org/10.1504/IJTM.2014.064588

Ginevicius, R., \& Korsakiene, R. (2005). The knowledge-based economy in Lithuania: Analysis of tendencies. Journal of Business Economics and Management, 6(4), 231-239.

Gnyawali, D. R., \& Park, B. J. R. (2011). Co-opetition between giants: Collaboration with competitors for technological innovation. Research Policy, 40(5), 650-663. https://doi.org/10.1016/j.respol.2011.01.009

Grant, R. M. (1996). Toward a knowledge-based theory of the firm. Strategic Management Journal, 17, $109-122$. https://doi.org/10.1002/smj.4250171110

Hagedoorn, J. (2002). Inter-firm R\&D partnerships: an overview of major trends and patterns since 1960. Research Policy, 31(4), 477-492. https://doi.org/10.1016/S0048-7333(01)00120-2

Hall, P., \& Wylie, R. (2014). Isolation and technological innovation. Journal of Evolutionary Economics, 24(2), 357-376. https://doi.org/10.1007/s00191-014-0347-7

Herstad, S. J., Aslesen, H. W., \& Ebersberger, B. (2014). On industrial knowledge bases, commercial opportunities and global innovation network linkages. Research Policy, 43(3), 495-504. https://doi.org/10.1016/j.respol.2013.08.003

Huber, G. (1998). Synergies between organizational learning and creativity \& innovation. Creativity and Innovation management, 7(1), 3-8. https://doi.org/10.1111/1467-8691.00079

Chatterjee, S., \& Hadi, A. S. (2013). Regression analysis by example. John Wiley \& Sons.

Chen, C. J., \& Huang, J. W. (2009). Strategic human resource practices and innovation performance-The mediating role of knowledge management capacity. Journal of Business Research,62(1), 104-114. https://doi.org/10.1016/ j.jbusres.2007.11.016

Cheng, C. C., \& Huizingh, E. K. (2014). When is open innovation beneficial? The role of strategic orientation. Journal of Product Innovation Management, 31(6), 1235-1253. https://doi.org/10.1111/jpim.12148

Chesbrough, H. W. (2003). Open Innovation: The New Imperative for Creating and Profiting from Technology. Harvard Business School Press, Boston, MA.

Chesbrough, H. W. (2006). Open innovation: A new paradigm for understanding industrial innovation. In Chesbrough, H. W., Vanhaverbeke, W., \& West, J. (Eds.), Open innovation: Researching a new paradigm. Oxford: Oxford University Press.

Chesbrough, H. W., \& Appleyard, M. M. (2007). Open innovation and strategy. California Management Review, 50(1), 5776. https://doi.org/10.2307/41166416

Chesbrough, H. (2010). Business model innovation: opportunities and barriers. Long Range Planning, 43(2), 354-363. https://doi.org/10.1016/j.lrp.2009.07.010

Chesbrough, H. W., Vanhaverbeke, W., \& West, J. (2006). Open Innovation: Researching a New Paradigm. Oxford University Press, Oxford, New York.

Innovation Union Scoreboard 2015, European Commission 2015, ISBN 978-92-79-44089-2, EU Publication Office, In: http://ec.europa.eu/growth/industry/innovation/facts-figures/scoreboards/index_en.htm

Kumar, N., \& Saqib, M. (1996). Firm size, opportunities for adaptation and in-house R \& D activity in developing countries: the case of Indian manufacturing. Research Policy, 25(5), 713-722. https://doi.org/10.1016/0048-7333(95)00854-3

Laursen, K., Masciarelli, F., \& Prencipe, A. (2012). Regions matter: how localized social capital affects innovation and external knowledge acquisition. Organization Science, 23(1), 177-193. https://doi.org/10.1287/orsc.1110.0650

Lee, H. H., Zhou, J., \& Hsu, P. H. (2015). The role of innovation in inventory turnover performance. Decision Support Systems, 76, 35-44. https://doi.org/10.1016/j.dss.2015.02.010

Miguel, P. C., \& Jorge, F. S. (2003). Order and disorder in product innovation, models. Creativity and Innovation Management, 12(3), 122-125.

Moreno, R., Paci, R., \& Usai, S. (2005). Spatial spillovers and innovation activity in European regions. Environment and Planning A, 37(10), 1793-1812. https://doi.org/10.1068/a37341

Mowery, D. C. (2009). Plus ca change: Industrial R\&D in the "third industrial revolution". Industrial and corporate change, 18(1), 1-50. https://doi.org/10.1093/icc/dtn049

Narula, R. (2002). Innovation systems and 'inertia'in R\&D location: Norwegian firms and the role of systemic lockin. Research policy, 31(5), 795-816. https://doi.org/10.1016/S0048-7333(01)00148-2 
Nelson, R. R. (1959). The simple economics of basic scientific research. Journal of Political Economy, 7(3), $297-306$. https://doi.org/10.1086/258177

Nieto, M., \& Quevedo, P. (2005). Absorptive capacity, technological opportunity, knowledge spillovers, and innovative effort. Technovation, 25(10), 1141-1157. https://doi.org/10.1016/j.technovation.2004.05.001

Oughton, C., Landabaso, M., \& Morgan, K. (2002). The regional innovation paradox: innovation policy and industrial policy. The Journal of Technology Transfer, 27(1), 97-110. https://doi.org/10.1023/A:1013104805703

Parida, V., Westerberg, M., \& Frishammar, J. (2012). Inbound open innovation activities in high-tech SMEs: the impact on innovation performance. Journal of Small Business Management, 50(2), 283-309. https://doi.org/10.1111/j.1540627X.2012.00354.X

Prochazka, O., \& Hajek, P. (2015). Modelling Knowledge Management Processes Using Fuzzy Cognitive Maps. In International Conference on Knowledge Management in Organizations (pp. 41-50). Springer International Publishing. https://doi.org/10.1007/978-3-319-21009-4_4

Rasula, J., Vuksic, V. B., \& Stemberger, M. I. (2012). The impact of knowledge management on organisational performance. Economic and Business Review, 14(2), 147-168.

Reed, R., Storrud-Barnes, S., \& Jessup, L. (2012). How open innovation affects the drivers of competitive advantage: Trading the benefits of IP creation and ownership for free invention. Management Decision, 50(1), 58-73. https://doi.org/10.1108/00251741211194877

Schneider, S., \& Spieth, P. (2013). Business model innovation: towards an integrated future research agenda. International Journal of Innovation Management, 17(1), 1-40. https://doi.org/10.1142/S136391961340001X

Siddharthan, N. S. (1992). Transaction costs, technology transfer, and in-house R\&D: a study of the Indian private corporate sector. Journal of Economic Behavior \& Organization, 18(2), 265-271. https://doi.org/10.1016/0167-2681(92)90031-6

StatSoft, Inc. (2011). STATISTICA (data analysis software system), version 10. www.statsoft.com.

Stejskal, J., \& Hajek, P. (2015). Modeling knowledge spillover effects using moderated and mediation analysis-The case of Czech high-tech industries. In International Conference on Knowledge Management in Organizations (pp. 329-341). Springer International Publishing. https://doi.org/10.1007/978-3-319-21009-4_25

Tseng, S. M. (2014). The impact of knowledge management capabilities and supplier relationship management on corporate performance. International Journal of Production Economics, 154, 39-47. https://doi.org/10.1016/j.ijpe.2014.04.009

Veugelers, R., \& Cassiman, B. (1999). Make and buy in innovation strategies: evidence from Belgian manufacturing firms. Research policy, 28(1), 63-80. https://doi.org/10.1016/S0048-7333(98)00106-1

Von Hippel, E. (1986). Lead users: a source of novel product concepts. Management science, 32(7), 791-805. https://doi.org/10.1287/mnsc.32.7.791

Von Hippel, E. (2005). Democratizing innovation: The evolving phenomenon of user innovation. Journal für Betriebswirtschaft, 55(1), 63-78. https://doi.org/10.1007/s11301-004-0002-8

Wang, Y., Vanhaverbeke, W., \& Roijakkers, N. (2012). Exploring the impact of open innovation on national systems of innovation - A theoretical analysis. Technological Forecasting and Social Change, 79(3), 419-428. https://doi.org/10.1016/j.techfore.2011.08.009

Weinberg, S. L., \& Abramowitz, S. K. (2002). Data analysis for the behavioral sciences using SPSS. Cambridge University Press.

Yang, J., \& Grabe, M. E. (2011). Knowledge acquisition gaps: A comparison of print versus online news sources. New Media \& Society, 13(8), 1211-1227. https://doi.org/10.1177/1461444811401708

The article has been reviewed.

Received in August, 2016; accepted in February, 2017. 